\title{
ANALISIS MUTU DAN EKONOMI PENERAPAN PENGEMASAN VAKUM BAWANG DAUN POTONGAN (Allium fistulosum L.) SELAMA PENYIMPANAN
}

\author{
Quality and Economic Analysis on Vacuum Packaging of Chopped Leeks (Allium \\ Fistulosum L.) During Storage
}

\author{
Florensi W. Mikael $^{1 *}$, R. Molenaar ${ }^{2}$, Lady C. CH. E.Lengkey ${ }^{2}$ \\ ${ }^{1}$ Mahasiswa Program Studi Teknik Pertanian. \\ ${ }^{2}$ Dosen Program Studi Teknik Pertanian. \\ Jurusan Teknologi Pertanian Fakultas Pertanian Universitas Sam Ratulangi \\ Jl. Kampus UNSRAT. Manado 95115 \\ *Email: florensiwahyuni@gmail.com
}

\begin{abstract}
This study aimed to analyze leeks packaging and without packaging during storage, and to analyze economical packaging and knowing the number of breakeven points obtained. This study uses an experimental method, and descriptive analysis of data consisting of 2 treatments and 3 replications, namely scallions which are vacuum packed, and leeks without packaging that are stored in a refrigerator with a temperature of $5-10^{\circ} \mathrm{C}$.

From the results of research on quality analysis of changes in weight, color and texture showed that the vacuum packaged onions at a storage temperature of $5^{\circ} \mathrm{C}-10^{\circ} \mathrm{C}$ gave the best results over a 14-day shelf life compared to unpacked leeks which only lasted for a shelf life of 6 days. Weight reduction occurred in the treatment without packaging by $44 \%$. The total fixed cost is Rp.219,625 /Year, the total variable cost is Rp.5,519 per package, with a yearly production of 24,300 packs /Year, to obtain the selling price of vacuum packaging leeks of Rp.6,080 per package, and the break-even analysis results in get is 392 packaging /Year.
\end{abstract}

Keywords : Leeks, Vacuum Packaging, Storage Time

\section{PENDAHULUAN}

Bawang daun (Allium fistulosum L.) merupakan salah satu jenis produk hortikultura yang banyak digunakan sebagai bumbu penyedap dalam berbagai olahan pangan (Cahyono, 2005). Setelah dipanen bawang daun masih melakukan proses metabolisme, Pra-pendinginan (precooling) berfungsi untuk melepaskan panas lapang dengan cepat sehingga laju aktivitas metabolisme dapat diperlambat, sehingga dapat menjaga mutu produk (Rokhani, 
1995). Pada saat ini mulai terbentuk pasar untuk produk sayuran yang sudah diolah minimal, mengingat banyaknya orang yang akan mengkonsumsi bawang daun tanpa harus membersihkannya dikarenakan menghemat waktu pengolahan. Sebagaimana bawang daun terolah minimal kerusakannya semakin cepat maka umur simpannya menjadi lebih pendek.

Salah satu teknik penanganan pasca panen yang dapat dilakukan adalah menggunakan pengemasan plastik secara vakum dikombinasikan dengan penyimpanan pada suhu rendah. Dengan adanya penggunaan kemasan vakum pada bawang daun terolah minimal maka adanya penambahan biaya pada produk tersebut. Tujuan Analisis ekonomi penerapan pengemasan vakum bawang daun untuk melakukan perhitungan-perhitungan agar pilihan kita tepat dalam usaha untuk melakukan investasi modal.

Penelitian ini bertujuan untuk menganalisis mutu bawang daun dengan kemasan vakum dan tanpa kemasan selama penyimpanan, dan menganalisis ekonomi kemasan vakum serta mengetahui nilai titik impas yang didapatkan.

\section{METODE PENELITIAN}

\section{Tempat dan Waktu Penelitian}

Penelitian ini dilaksanakan di Laboratorium Keteknikan Pertanian, Jurusan Teknologi Pertanian, Fakultas Pertanian, Universitas Sam Ratulangi Manado. Penelitian ini berlangsung pada bulan September sampai November 2019.

\section{Alat dan Bahan}

Alat yang digunakan dalam penelitian ini yaitu, vacuum sealer, pisau stainless steel, termometer batang, termometer digital, timbangan manual/duduk, timbangan analitik, lemari pendingin, penetrometer Fruit Texture
Analyser, handphone samsung m20, aplikasi Color Grab, kotak "styrofoam" dan alat tulis menulis.

Bahan utama yang digunakan adalah daun bawang, plastik refill vacuum roll ukuran $20 \times 500 \mathrm{~cm}$, air dingin dan es batu.

\section{Rancangan Penelitian}

Penelitian ini menggunakan metode percobaan/(eksperimen), dan analisis data secara deskriptif yang terdiri dari 2 perlakuan dan 3 kali ulangan, yaitu daun bawang yang dikemas secara vakum, dan daun bawang tanpa kemasan yang disimpan pada lemari pendingin dengan suhu $5-10^{\circ} \mathrm{C}$. Data hasil pengamatan dan perhitungan kemudian di plot ke dalam tabel, gambar, dan grafik kemudian dikaji secara deskriptif, yaitu menjelaskan kehilangan berat, warna, dan tekstur yang terjadi pada daun bawang selama penyimpanan.

\section{Prosedur Penelitian}

1) Bawang daun yang digunakan dalam penelitian ini berumur 2,5 bulan dengan ciri fisik daunnya bewarna hijau segar yang dipanen langsung dari kebun petani kemudian dibawa ke Laboratorium Keteknikan Fakultas Pertanian, Universitas Sam Ratulangi.

2) Sebelum dicuci bawang daun dibersihkan dan disortir, penyortiran dilakukan untuk membuang bawang daun yang telah rusak secara fisik (lecet, pecah, atau terkena hama) selanjutnya dicuci dengan menggunakan air bersih.

3) Kemudian bawang daun di lakukan prapendinginan sesuai perlakuan selama 15 menit dimana bertujuan untuk memperlambat respirasi, menurunkan kepekaan terhadap serangan mikroba, dan juga untuk memperpanjang umur simpan produk selama penyimpanan.

4) Setelah itu dilakukan penirisan (selain mengurangi air setelah pra-pendinginan juga memudahkan dalam pengemasan) 
dan trimming (pemotongan) panjang bawang daun $27 \mathrm{~cm}$ dengan ukuran plastik lebar $20 \mathrm{~cm}$ panjang $32 \mathrm{~cm}$.

5) Kemudian bawang daun akan ditimbang untuk masing-masing ulangan seberat 200 gram, dan dilakukan pengamatan terlebih dahulu sebelum daun bawang dikemas dan disimpan. Untuk mengetahui data awal (0 hari pengamatan) dilakukan pengukuran perubahan susut berat, perubahan warna, dan tekstur.

6) Bawang daun yang telah dikemas, disimpan di lemari pendingin dengan suhu $5-10^{\circ} \mathrm{C}$.

7) Selanjutnya pengamatan dilakukan setiap 2 hari sekali. Setiap 2 hari sekali dilakukan pengukuran perubahan susut berat, perubahan warna, dan tekstur.

\section{Susut Berat}

Untuk mengukur perubahan berat pada bahan adalah dengan cara menimbang sampel, berat awal dan berat setelah penyimpanan, selisih diantara keduanya dinyatakan sebagai perubahan berat. Perubahan berat dapat dihitung berdasarkan persamaan :

$$
W=\frac{A-B}{A} \times 100 \%
$$

Keterangan :

W: Perubahan berat

A: Berat bawang daun awal

B: Berat bawang daun Hari ke-n

\section{Perubahan Warna}

Warna pada sayuran merupakan salah satu parameter ukuran mutu pada sayuran. Bila warna pada sayuran kurang baik maka nilainya akan berkurang karena tidak menarik bagi konsumen. Warna dapat meningkatkan daya tarik dan dalam kebanyakan kasus digunakan dalam petunjuk kemasan, selain itu warna juga berhubungan dengan rasa, bau, tekstur dan nilai gizi dan keutuhan.

Pengujian dan pengukuran warna bertujuan untuk menentukan proses perubahan warna selama proses penyimpanan dan mengontrol laju perubahan kualitas dari bahan itu sendiri dengan menggunakan aplikasi Color Grab.

Analisis warna menggunakan aplikasi Color Grab dengan cara sebagai berikut :

1) Buka aplikasi Color Grab pada handphone samsung tipe $\mathrm{m} 20$

2) Kemudian tekan dua kali pada kamera sampe telah terfokus pada sampel yang akan dianalisis

3) Hasil analisis warna dapat dilihat dengan tekan pada conversions, sehingga nilai 1 , -a, b, dan warna pada sampel akan terlihat.

\section{Tekstur}

Tekstur bawang daun diukur dengan menggunakan Fruit Texture Analyser dengan cara sebagai berikut :

1. Ambil Sampel bawang daun sesuai perlakuan.

2. Letakkan Sampel di bawah penetrometer, atur hingga dapat menyentuh sampel.

3. Atur penetrometer dengan tekan start test hingga telah terbaca ready. Kemudian tekan tombol pada Fruit Texture Analyser hingga terdengar bunyi dan atur sehingga akan menyentuh sampel bawang daun dengan 3 posisi berbeda pada bawang daun, yaitu: bagian tengah, pangkal atas, dan pangkal bawah.

4. Kemudian catat angka yang tertera pada LCD/Keypad pada Fruit Texture Analyser.

\section{Analisis Ekonomi \\ Biaya Tetap (Fixed Cost)}

Jenis-jenis biaya tidak tetap dalam 
penelitian ini adalah :

a) Biaya penyusutan alat dihitung berdasarkan Metode Garis Lurus (MGL) dengan nilai sisa asset 10\%, dihitung dalam persamaan 1 .

b) Bunga modal alat dihitung dengan tingkat bunga $5 \%$ per tahun dihitung dalam persamaan 2 .

Biaya Tidak Tetap (Variable cost)

Jenis-jenis biaya tidak tetap dalam penelitian ini adalah :

a) Biaya bahan baku bawang daun diasumsikan $5 \mathrm{~kg}$ dengan harga Rp.40.000, dan berat bawang daun per kemasan 200 gram, dihitung dalam persamaan 3.

b) Biaya plastik vakum diasumsikan 1 roll panjang $500 \mathrm{~cm}$ dengan harga Rp.44.000, dihitung dalam persamaan 4.

c) Biaya pra-pendinginan bawang daun kemasan vakum diasumsikan $12 \mathrm{~kg}$ es batu dengan harga Rp.8.568 dalam 1 kali precooling sebanyak $5 \mathrm{~kg}$ bawang daun, dihitung dalam persamaan 5 .

d) Biaya pemakaian listrik untuk alat vakum sealer dengan daya hantar 175 W dan tarif dasar listrik Rp.1.352 kwh, dihitung dalam persamaan 6 .

e) Biaya operator/upah tenaga kerja untuk pengemasan vakum bawang daun yaitu, dimana jumlah operator 1 orang, jam kerja perhari selama 2 jam untuk 27 kemasan, dan upah operator per orang per jam Rp.10.000, dihitung dalam persamaan 7 .

f) Biaya pengangkutan, diasumsikan satu kali perjalanan sebesar Rp. 150.000 dalam waktu 1 jam dari arah Tomohon menuju ke laboratorium keteknikan pasca panen dengan menggunakan mobil pick up yang berkapasitas 1.5 ton untuk melakukan proses pengemasan vakum dalam, dihitung dalam persamaan 8 .

\section{Biaya Produksi}

Biaya produksi semua biaya yang berkaitan dengan bawang daun kemasan vakum yang dinyatakan dalam satuan rupiah kemasan.

\section{Harga Jual}

Harga jual produk adalah harga penjualan bawang daun kemasan vakum yang dinyatakan dalam satuan rupiah per kemasan.

Analisis Titik Impas (Break Even Point)

Analisis titik impas adalah hasil yang didapat dengan perhitungan biaya tetap, tidak tetap, dan harga jual bawang daun kemasan vakum, dan dinyatakan dalam kemasan per tahun

\section{HASIL DAN PEMBAHASAN}

Suhu Udara dan Kelembaban Udara

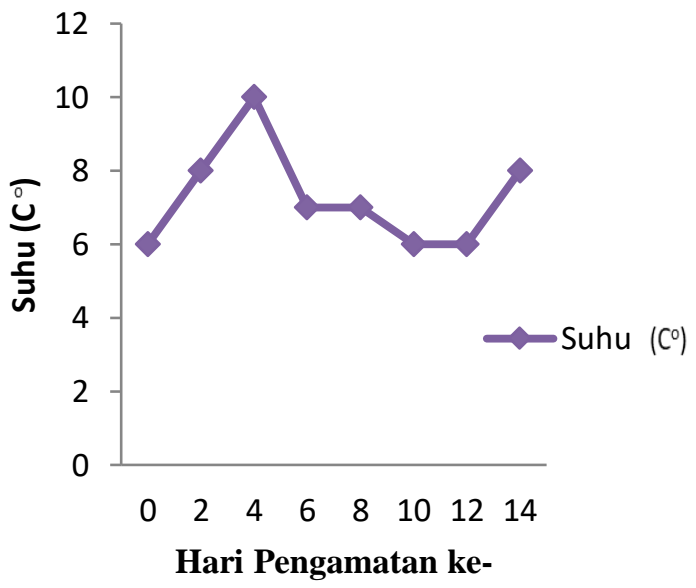

Gambar 1. Suhu udara lemari pendingin selama penyimpanan

Dari data suhu udara lemari pendingin selama penyimpanan (gambar 1), maka diperoleh data kelembaban udara lemari pendingin selama penyimpanan disajikan pada Gambar 2. 


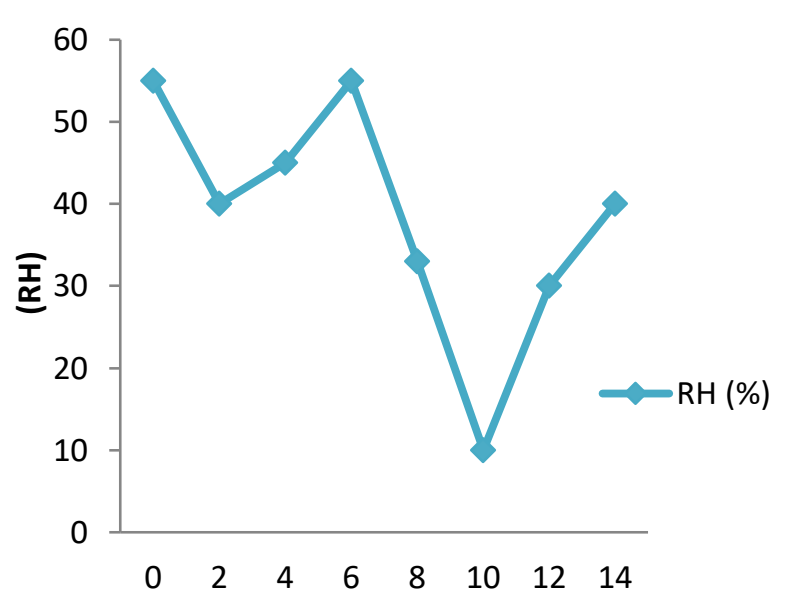

Hari Pengamatan ke-

Gambar 2. Kelembaban udara lemari pendingin selama penyimpanan

\section{Perubahan Berat}

Perubahan berat merupakan salah satu faktor yang digunakan untuk mengidentifikasi mutu fisik bawang daun. Perubahan berat bawang daun berubah bersamaan dengan lamanya waktu penyimpanan.

Gambar 3 menunjukkan bawang daun kemasan vakum pada suhu simpan $5^{\circ} \mathrm{C}-10^{\circ} \mathrm{C}$ tidak terjadi perubahan berat selama penyimpanan. Bawang daun yang dikemas vakum mengalami sedikit peningkatan berat pada hari ke 2 sebesar $202,77 \mathrm{~g}$, hari ke 4 sebesar 202,95 g, dan hari ke 6 sebesar 203,17 g kemudian turun kembali disebabkan, karena suhu pada bahan dan suhu lingkungan tidak relatif sehingga terjadinya kondensasi atau pengembunan. Terjadinya kondensasi mengakibatkan adanya air didalam kemasan karena perbedaan suhu antara suhu bahan dan suhu lingkungan.

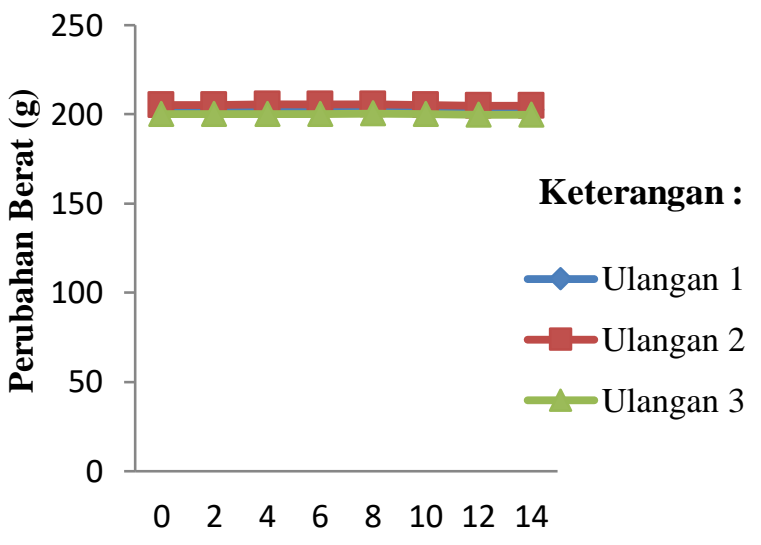

Hari Pengamatan Ke-

Gambar 3. Rata-rata perubahan berat bawang daun kemasan vakum (g) pada suhu $5 \mathrm{C}^{\circ}-10^{\circ} \mathrm{C}$ selama penyimpanan.

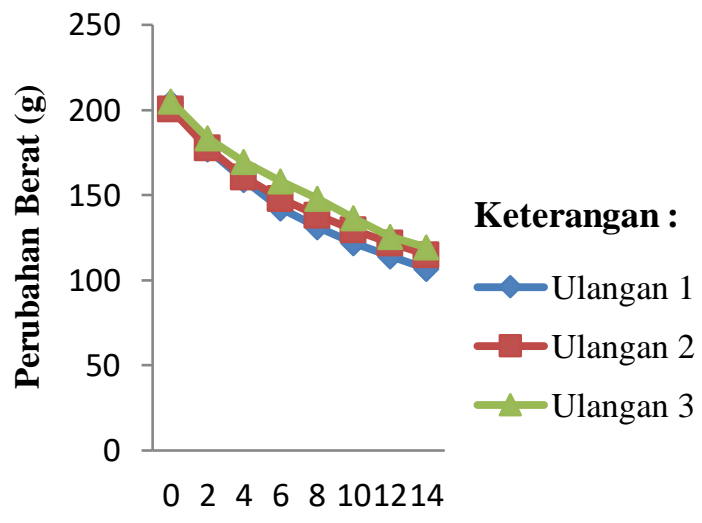

Hari Pengamatan ke-

Gambar 4. Rata-rata perubahan berat daun bawang tanpa kemasan (g) pada suhu $5 \mathrm{C}^{\mathrm{O}}-10^{\circ} \mathrm{C}$ selama penyimpanan

Gambar 4 menunjukkan perubahan berat bawang daun tanpa kemasan pada suhu simpan $5^{\circ} \mathrm{C}-10^{\circ} \mathrm{C}$ mengalami penurunan berat selama penyimpanan, pada hari ke 2 sebesar 179,43 g, hari ke 6 149,46 g, dan 113,76 g setelah penyimpanan 14 hari, susut berat ini disebabkan proses transpirasi dan respirasi sehingga mengakibatkan bawang daun mengalami susut berat. Menurut Wills et al. (1981), pada proses respirasi senyawa- 
senyawa kompleks yang biasa terdapat dalam sel seperti karbohidrat akan dipecah menjadi molekul-molekul yang sederhana seperti karbondioksida dan air yang mudah menguap, sehingga komoditas akan kehilangan bobotnya. Kehilangan air pada komoditas tergantung dari defisit tekanan uap air antara komoditas dengan udara sekitar. Pada kelembaban nisbi udara (RH) dan laju pergerakan udara tertentu, kehilangan air dari komoditas akan meningkat sejalan meningkatnya temperatur.

Selama penyimpanan daun bawang pada suhu simpan $5^{\circ} \mathrm{C}-10^{\circ} \mathrm{C}$ dan kelembaban udara $(\mathrm{RH})$ mengalami naik turun dari (RH) 55\% menjadi (RH) $10 \%$. Dengan naik turunnya suhu dan rendanhnya RH mengakibatkan terjadinya penguapan dan terjadi susut berat. Proses penguapan air dalam bahan dengan spontan berubah menjadi gas (contohnya uap air). Menurut Finger (1999), kecepatan susut berat pada sayuran sangat dipengaruhi oleh suhu dan kelembaban udara pada ruang penyimpanan. Semakin tinggi suhu dan rendahnya kelembaban udara maka laju respirasi akan semakin tinggi sehingga menurunkan berat dari bahan tersebut.

Bawang daun pada pengemasan vakum pada perlakuan suhu penyimpanan yang rendah bisa mempertahankan kesegaran karena proses laju respirasi terhambat, dan mencegah terjadinya pertumbuhan mikroorganisme sehingga kesegaran bawang daun yang dikemas akan bertahan lebih lama. Menurut Syarif dan Halid (1993), bahan pengemas dan suhu rendah dapat menekan laju respirasi serta mempertahankan kesegaran.

Kehilangan air selama penyimpanan tidak hanya menurunkan berat, tetapi juga dapat menurunkan mutu dan menimbulkan kerusakan. Kehilangan yang hanya sedikit mungkin tidak akan mengganggu tetapi kehilangan yang banyak akan menyebabkan kelayuan dan pengkriputan (Muchtadi, 1992). Pada bawang daun tanpa kemasan hari ke 6 mulai terjadinya kelayuan dan pengkriputan (gambar 5).

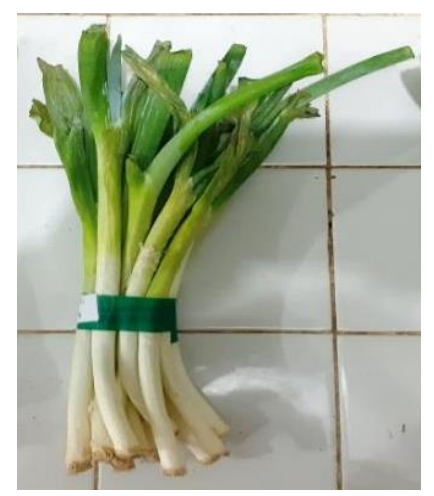

Gambar 5. Bawang daun tanpa kemasan pada suhu $5^{\circ} \mathrm{C}-10^{\circ} \mathrm{C}$ hari ke 6

\section{Perubahan Warna}

Warna bahan pangan selama penyimpanan akan mengalami perubahan yang dipengaruhi kondisi penyimpanan. Hasil Pengujian dan pengukuran warna pada bawang daun menggunakan aplikasi color grab pada smartphone yang dilakukan selama penyimpanan mengalami perubahan warna. Hal tersebut dapat di lihat pada tabel 1 dan 2.

Tabel 1 menunjukkan bawang daun pada kemasan vakum yang disimpan pada suhu penyimpanan $5^{\circ} \mathrm{C}-10^{\circ} \mathrm{C}$ mengalami perubahan warna selama penyimpanan, dimana pada hari ke 0 sampai hari ke 12 bawang daun hijau segar berubah menjadi hijau gelap dan pada hari ke 14 warna daun bawang berubah menjadi hijau kecoklatan dan sudah mulai adanya bau busuk dengan penampakan fisik daunnya berlendir tetapi batangnya masih terlihat tegar. 
Tabel 1. Perubahan Warna Bawang Daun Kemasan Vakum

\begin{tabular}{clccc}
\hline \multirow{2}{*}{$\begin{array}{c}\text { Hari } \\
\text { ke- }\end{array}$} & \multicolumn{1}{c}{ Warna (Hijau tua) } & L & A & Bata-rata \\
\cline { 3 - 5 } & & 26,40 & $-25,33$ & 19,67 \\
2 & Hijau tua (myrtle) & 29,87 & $-24,33$ & 17,80 \\
4 & Hijau tua (myrtle) & 31,30 & $-24,47$ & 20,90 \\
6 & Hijau tua (kaitoke green) & 34,03 & $-25,37$ & 20,20 \\
8 & Hijau tua (kaitoke green) & 35,10 & $-26,57$ & 21,60 \\
10 & Hijau tua (parsley) & 38,03 & $-27,37$ & 19,60 \\
12 & Hijau tua (tom thumb) & 40,57 & $-28,13$ & 17,47 \\
14 & Hijau gelap (japanese laurel) & 42,05 & $-33,50$ & 28,00 \\
\hline
\end{tabular}

Tabel 2. Perubahan Warna Bawang Daun Tanpa Kemasan

\begin{tabular}{clccc}
\hline Hari & \multicolumn{1}{c}{ We- } & \multicolumn{3}{c}{ Rata-rata } \\
\cline { 3 - 5 } & & L & A & B \\
\hline 0 & (myrtle) & 38,53 & $-32,17$ & 24,27 \\
2 & (green house) & 38,50 & $-31,57$ & 21,37 \\
4 & (sanfelix) & 35,33 & $-30,17$ & 23,07 \\
6 & (hippie green) & 30,40 & $-23,57$ & 18,63 \\
\hline
\end{tabular}

Data $\mathrm{L}=$ menyatakan cahaya pantul yang menghasilkan warna akromatik putih, abu-abu dan hitam. Nilai $\mathrm{L}$ berkisar antara 0 (hitam) - 100 (putih).

$-\mathrm{A}=$ menyatakan warna kromatik campuran merah - hijau. Nilai $:+$ A dari $0-100$ untuk warnah merah $-\mathrm{A}$ dari 0 - (-80) untuk warna hijau.

$\mathrm{B}=$ menyatakan warna kromatik campuran biru - kuning. Nilai $:+\mathrm{B}$ dari 0-70 untuk warna kuning.

Tabel 2 menunjukkan bawang daun tanpa kemasan yang disimpan pada suhu penyimpanan $\quad 5^{\circ} \mathrm{C}-10^{\circ} \mathrm{C}$ mengalami perubahan warna selama penyimpanan, dimana pada penyimpanan hari ke 6 daunnya sudah mulai mengalami perubahan warna dari hijau segar berubah menjadi hijau pudar kekuningan dengan penampakan fisik adanya pelayuan dan pengkriputan.

\section{Perubahan Tekstur}

Untuk menentukan nilai kekerasan / tekstur pada bawang daun diukur dengan menggunakan Fruit Texture Analyser. Nilai tekstur yang semakin rendah selama penyimpanan menunjukkan bahwa bawang daun mengalami pelunakan. Hasil pengamatan perubahan tekstur disajikan pada gambar 6 dan 7 .
- Pangkal Atas $\square$ Tengah $\square$ Pangkal Bawah

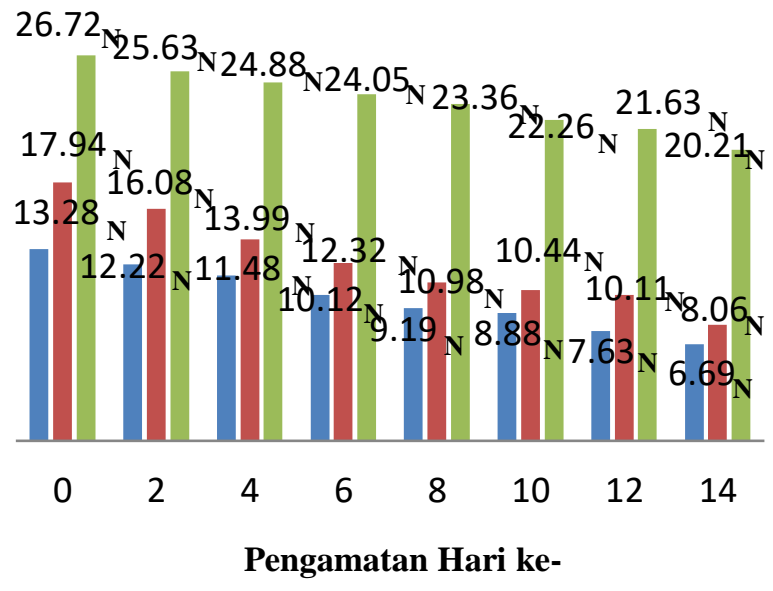

Gambar 6. Rata-rata tekstur daun bawang (N) kemasan vakum pada suhu $5^{\circ} \mathrm{C}-10^{\circ} \mathrm{C}$. 
Gambar 6 menunjukkan bahwa nilai kekerasan atau tekstur semakin turun dengan seiring waktu penyimpanan. Tekstur bawang daun kemasan vakum yang di simpan pada suhu $5^{\circ} \mathrm{C}-10^{\circ} \mathrm{C}$ selama 14 hari penyimpanan menunjukkan adanya perubahan. Pada kemasan vakum nilai kekerasan bawang daun hari ke 0 pada bagian pangkal atas sebesar 13,28 N, bagian tengah sebesar sebesar 17,94 $\mathrm{N}$, dan pangkal bawah sebesar 26,72 N. Setelah penyimpanan selama 14 hari nilai kekerasan daun bawang pada bagian pangkal atas sebesar 6,69 N, bagian tengah sebesar sebesar 8,06 N, dan pangkal bawah sebesar $20,21 \mathrm{~N}$.
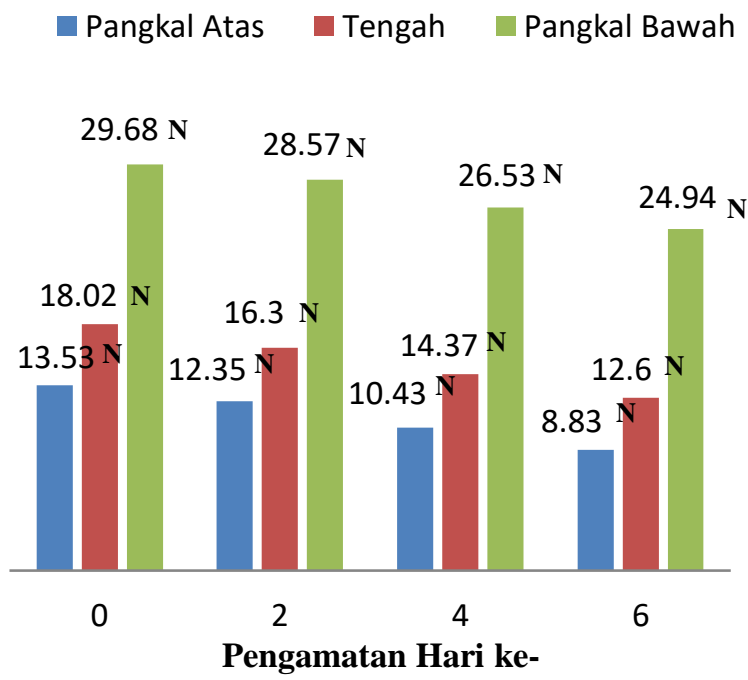

Gambar 7. Rata-rata tekstur bawang daun (N) tanpa kemasan pada suhu $5^{\circ} \mathrm{C}-$ $10^{\circ} \mathrm{C}$

Gambar 7 menunjukkan bahwa nilai kekerasan atau tekstur semakin turun dengan seiring waktu penyimpanan. Tekstur bawang daun tanpa kemasan yang di simpan pada suhu $5^{\circ} \mathrm{C}-10^{\circ} \mathrm{C}$ selama 6 hari penyimpanan. Nilai kekerasan bawang daun tanpa kemasan vakum pada suhu $5^{\circ} \mathrm{C}-10^{\circ} \mathrm{C}$ hari ke 0 pada bagian tengah sebesar 13,53
$\mathrm{N}$, bagian tengah sebesar sebesar 18,02 N, dan pangkal bawah sebesar 29,68 N. Setelah penyimpanan selama 6 hari nilai kekerasan bawang daun pada bagian pangkal atas sebesar 8,83 N, bagian tengah sebesar sebesar 12,6 N, dan pangkal bawah sebesar $24,94 \mathrm{~N}$.

Aktivitas respirasi dan transpirasi yang tinggi pada bawang daun menyebabkan kehilangan air yang cukup banyak sehingga ukuran sel dan tekanan isi sel terhadap dinding sel berkurang yang mengakibatkan tekstur menjadi lunak. Penurunan kekerasan selama penyimpanan terjadi karena perombakan komponen penyusun dinding sel sehingga buah semakin lunak.

Pada bawang daun yang dikemas vakum disimpan pada suhu $5^{\circ} \mathrm{C}-10^{\circ} \mathrm{C}$ mengalami penurunan nilai kekerasan selama 14 hari penyimpanan, dan tekstur pangkal bawang daun yang dikemas secara vakum memberikan nilai kekerasan yang lebih baik dengan penampakan fisik daunnya mulai berlendir tetapi pada pangkal bawang daun masih terlihat tegar dan bisa bertahan lebih lama untuk penyimpanan. Menurut Syarif dan Halid (1993), bahan pengemas dan suhu rendah dapat menekan laju respirasi serta mempertahankan kesegaran. Sedangkan bawang daun tanpa kemasan yang disimpan pada suhu $5^{\circ} \mathrm{C}-10^{\circ} \mathrm{C}$ mengalami penurunan nilai kekerasan tetapi hanya mampu bertahan selama 6 hari penyimpanan, dimana pangkal bawang daun menjadi kering dan keras dan daunnya sudah mulai bewarna kuning. Hal ini disebabkan perubahan tekstur yang terjadi pada bawang daun akibat tingginya transpirasi menyebabkan kehilangan air yang cukup banyak kehilangan air yang banyak akan menyebabkan kelayuan dan pengkriputan. 


\section{Biaya Tetap (Fixed Cost)}

Perhitungan biaya tetap pada proses pengemasan vakum bawang daun meliputi alat vakum sealer, timbangan manual/duduk, dan kotak Styrofoam. Biaya alat/bahan pengemasan vakum bawang daun dapat dilihat pada tabel 3 .

\section{A. Biaya Penyusutan}

Perhitungan biaya penyusutan peralatan dihitung berdasarkan umur ekonomis asset 10 tahun dan nilai sisa suatu alat $10 \%$, maka hasil analisis perhitungan biaya penyusutan alat dapat dilihat pada tabel 4.

\section{B. Biaya bunga modal}

Perhitungan biaya bunga modal alat dihitung dengan tingkat bunga $5 \%$, maka hasil analisis perhitungan biaya bunga modal alat dapat dilihat pada tabel 5 .

Dengan demikian maka total biaya penyusutan alat yaitu sebesar Rp.184.500/Tahun atau sebesar 10\% dari harga awal, dan total biaya bunga modal yaitu sebesar Rp.35.125/Tahun dengan tingkat bunga $5 \%$ sehingga hasil total biaya tetap pengemasan vakum daun bawang adalah sebesar Rp.219.625.

\section{Biaya Tidak Tetap (Variable Cost)}

Perhitungan biaya tidak tetap pada proses pengemasan vakum bawang daun meliputi biaya bahan baku, biaya plastik, biaya pra-pendinginan/es batu, upah operator, biaya pemakaian listrik, dan biaya pengangkutan. Hasil perhitungan biaya tidak tetap pada proses pengemasan vakum bawang daun dapat dilihat pada tabel 6 .

\section{Biaya Produksi}

Pada penentuan biaya produksi bawang daun jika jam kerja 1 hari 6 jam menghasilkan 81 kemasan sehingga produksi bawang daun dalam setahun adalah 300 hari $/$ efektif kerja $\times 81$ kemasan $=24.300$ kemasan/Tahun.

Dari hasil penentuan biaya produksi bawang daun kemasan vakum dalam setahun diperoleh 24.300 kemasan/tahun kemudian dibagi dengan total biaya tetap Rp.219.625/Tahun sehingga diperoleh biaya tetap per kemasan adalah Rp.9, dan ditambah dengan biaya tidak tetap Rp.5.519 per kemasan, sehingga diperoleh biaya produksi sebesar Rp.5.528 kemasan.

Tabel.3.Analisis biaya alat/bahan pengemasan vakum bawang daun

\begin{tabular}{llcc}
\hline No. & \multicolumn{1}{c}{ Alat / Bahan } & Jumlah & Harga (Rp) \\
\hline 1. & Alat vakum sealer & 1 & 800.000 \\
2. & Timbangan manual / duduk & 1 & 350.000 \\
3. & Kotak Styrofoam & 1 & 50.000 \\
\hline
\end{tabular}

Tabel.4. Analisis hasil biaya total penyusutan peralatan pengemasan vakum daun bawang

Jenis Biaya Tetap

Alat vakum sealer

Timbangan manual / duduk

Kotak Styrofoam
Biaya Penyusutan Peralatan (Rp/tahun)

144.000

31.500

9.000

\section{Jumlah}

184.500 
Tabel.5. Analisis hasil biaya bunga modal pengemasan vakum bawang daun

Jenis Biaya Tetap

Alat vakum sealer

Timbangan manual / duduk

Kotak Styrofoam
Biaya Bunga Modal (Rp/tahun)

24.000

9.625

1.500

Jumlah

35.125

Tabel 6. Analisis hasil biaya tidak tetap pengemasan vakum bawang daun

\begin{tabular}{lc}
\hline \multicolumn{1}{c}{ Jenis Biaya } & Biaya Tidak Tetap (Rp/kemasan) \\
\hline Biaya bahan baku & 1.600 \\
Biaya plastik vakum & 2.816 \\
Biaya es batu & 342 \\
Biaya operator & 740 \\
Biaya pemakaian listrik & 1,4 \\
Biaya pengangkutan & 20 \\
\hline \multicolumn{1}{c}{ Jumlah } & $\mathbf{5 . 5 1 9}$ \\
\hline
\end{tabular}

\section{Harga Jual}

Harga jual yang didapatkan berdasarkan perhitungan persamaan 11 adalah sebesar Rp.6.080 per kemasan.

Analisis Titik Impas (Break Even Point)

Titik impas yang didapatkan berdasarkan perhitungan persamaan 12 adalah 392 Kemasan/Tahun.

\section{KESIMPULAN}

Dari hasil penelitian analisis mutu perubahan berat, warna dan tekstur menunjukkan bahwa bawang daun yang dikemas vakum pada suhu simpan $5^{\circ} \mathrm{C}-10^{\circ} \mathrm{C}$ memberikan hasil yang paling baik selama masa simpan 14 hari. Total biaya tetap sebesar Rp.219.625/Tahun, total biaya tidak tetap Rp.5.519 per kemasan, dengan produksi setahun Rp.24.300 kemasan/Tahun, sehingga diperoleh harga jual daun bawang kemasan vakum sebesar Rp.6.080 per kemasan, dan hasil analisis titik impas yang di dapatkan adalah 392 kemasan/Tahun.

\section{DAFTAR PUSTAKA}

Cahyono, B. 2005. Teknik Budidaya dan Analisis Usaha Tani Bawang Daun. Kanisius. Yogyakarta.

Finger, FL, Endres, L, Mosquim \& Puiatti, M 1999, 'Physiological changes during postharvest senescence of broccoli', Pesq. Agropec. Bras., Brasília, vol. 34, no, 9, pp. 1565-9.

Muchtadi, Deddy. 1992. Fisiologi Pasca Panen Sayuran dan Buah-buahan. Departemen Pendidikan Dan Kebudayaan Direktorat Jenderal Pendidikan Tinggi Pusat Antar Universitas Pangan Dan Gizi IPB, Bogor.

Rokhani H. 1995. Mempelajari Laju Transpirasi dan Pengaruh Komposisi Gas pada Penyimpanan Brokoli secara Controlled Atmosphere [Laporan Penelitian]. Bogor: Jurusan Mekanisasi Pertanian FATETA Institut Pertanian Bogor.

Syarief, R dan H. Halid. 1993. Teknologi Penyimpanan Pangan. Arcan Press, 
Jurnal Teknologi Pertanian Volume 11 Nomor 2 Desember 2020

Jakarta.

Wills, R.A.H., T.H. Lee, D. Graham, W.B. McGlasson, E.G. Hall. 1981. Postharvest An Introduction to the Physiology and Handling of Fruit and vegetables. New South Wales University Press. Sydney. 